Egyptian Journal of Aquatic Biology \& Fisheries

Zoology Department, Faculty of Science,

Ain Shams University, Cairo, Egypt.

ISSN $1110-6131$

Vol. 25(3): $531-550$ (2021)

www.ejabf.journals.ekb.eg

\title{
Antiproliferative and antioxidant activities of the edible crab Callinectes sapidus
} hepatopancreas and hemolymph extracts

\author{
Somaia M. Zakzok ${ }^{1}$, Rabab M. Alkaradawe ${ }^{2}$,Samya H. Mohammad ${ }^{1}$, \\ Mohamed M. Tawfik ${ }^{1^{*}}$ \\ '. Zoology Departement, Faculty of Science, Port Said University, Egypt. \\ ${ }^{2}$. Zoology Departement, Faculty of Science, El-Arish University, Egypt. \\ "Corresponding Author: Tawfik@sci.psu.edu.eg
}

\section{ARTICLE INFO \\ Article History: \\ Received: May 26, 2021 \\ Accepted: June 22, 2021 \\ Online: June 24, 2021}

Keywords:

Blue crabs,

Hepatopancreas,

Hemolymph,

Antiproliferative,

Apoptosis,

Antioxidant.

\begin{abstract}
Crabs, decapods crustaceans, have been recognized as a rich natural source of unique antioxidant and therapeutic agents. Callinectes sapidus is an edible crab used as a popular food source in coastal cities like Port Said, Egypt. In the present study, in vitro cytotoxic and antioxidant properties of the hepatopancreas and hemolymph of $C$. sapidus were investigated on some human cell lines (HeLa, HepG 2, MCF-7, MDA-MB-231 and WI38). The MTT results showed that both extracts possess selective cytotoxicity against HepG2, MCF-7 and HeLa. No cytotoxicity was observed on normal lung cells (WI-38). The hepatopancreas and hemolymph showed the highest antiproliferative activity against HeLa cells $\left(\mathrm{IC}_{50}: 0.39\right.$ and $2.01 \mathrm{mg} / \mathrm{ml}$ respectively). Flow cytometry revealed that both extracts can induce apoptosis in HeLa cells and cause cell cycle arrest in the G2/M phase after $48 \mathrm{~h}$ treatment. Hepatopancreas showed greater DPPH radical-scavenging activity with $\mathrm{IC}_{50}$ value of $38.99 \mu \mathrm{g} / \mathrm{ml}$ than hemolymph $\left(\mathrm{IC}_{50}\right.$ value of $\left.464 \mu \mathrm{g} / \mathrm{ml}\right)$. Both extracts at $2 \mathrm{mg} / \mathrm{ml}$ were effective to attenuate the perturbations in the tested parameters (superoxide dismutase, catalase, reduced glutathione and malondialdehyde) of $\mathrm{H}_{2} \mathrm{O}_{2}$-induced oxidative stress in WI-38 cells. Findings suggest that these blue crab extracts have protective effects on $\mathrm{H}_{2} \mathrm{O}_{2}$-induced lipid peroxidation and might be used for the development of new drugs against human cervical adenocarcinoma.
\end{abstract}

\section{INTRODUCTION}

A remarkable number of novel bioactive agents have been isolated from marine invertebrates such as sponges, molluscs, cnidarians and crustaceans due to the unique biological and chemical diversity of the marine environment (Abou El-Ezz et al., 2017; Blunt et al., 2018). Among crustaceans, crabs represent a potential source of various natural antioxidants and anticancer molecules (Datta et al., 2016; Katran et al., 2019). Crabs are continuously exposed to several stress factors, such as microbes, pathogens and changes in environmental and physiological conditions, leading to enhance oxidative 
stress. Moreover, like invertebrates, crabs lack adaptive immune system. Therefore they have been assumed to exhibit a rich variation of effective innate immune responses and have developed antioxidant defense systems to protect themselves (Sánchez-Salgado $\boldsymbol{e} t$ al., 2017; Huang et al., 2020).

The hepatopancreas and hemolymph play crucial defensive and immunological roles in crabs (Rőszer, 2014). Hepatopancreas is responsible for the elimination and detoxification of xenobiotics (Ortega $\boldsymbol{e t}$ al., 2011). This digestive gland is the primary site for the synthesis and production of some immune response molecules such as lectins, hemocyanin, serine protease inhibitors, stress proteins, antimicrobial and apoptotic peptides (Shi et al., 2010; Li et al., 2013; Wei et al., 2020). Similarly, hemolymph is an important defense line in crabs. It includes hemocytes, the main immune cells, which perform various immunological functions such as phagocytosis, encapsulation, lysis of foreign bodies and release of humoural proteins (Parrinello et al., 2015; Wu et al., 2019). The hemolymph of crabs exhibits potent anticancer activities that have been investigated in Atergatis roseus and Eriphia verrucosa (Salama and Mona, 2018), Dromia dehanni (Priya and Ravichandr, 2015a; RethnaPriya et al., 2019) and Calappa calappa (Priya and Ravichandr, 2015b).

The blue crab Callinectes sapidus (Crustacea: Decapoda: Portunidae) is widely distributed along the Mediterranean coast of Port Said, Egypt. This edible crab is one of the most valuable sources of nutrition for human consumption since it is enriched with proteins, minerals, vitamins and omega-3 fatty acids (Küçükgülmez et al., 2006). However, there is little attention that has been given to investigating or evaluating the biological activities of these blue crab extracts.

The current study was carried out to assess the potential antiproliferative activities of hepatopancreas and hemolymph extracts of $C$. sapidus against some human cell lines and investigate the cytoprotective properties of both extracts on $\mathrm{H}_{2} \mathrm{O}_{2}$-treated lung cells in vitro.

\section{MATERIALS AND METHODS}

\section{Sample collection}

Live blue crabs were collected in 2018 from the Mediterranean Sea in Port Said, Egypt. Samples were transported in tanks to the laboratory of the Zoology department, Faculty of Science, Port Said University. The crabs were cryoanesthetized on ice for 15 min.

\section{Hemolymph and Hepatopancreas collection}

Hemolymph was withdrawn from the base of the swimming legs of the blue crabs using fine sterile syringes. Then, hemolymph was mixed with sodium citrate buffer, $\mathrm{pH}$ $4.6(3: 1 \mathrm{v} / \mathrm{v})$ as an anticoagulant to prevent hemocytes degranulation and coagulation 
(Sivaperumal et al., 2013). After that, the crabs were dissected in order to separate and collect the hepatopancreas. The hepatopancreas was then mixed with $50 \mathrm{mM}$ Tris/ $\mathrm{HCl}$ at pH $8.0(4 \mathrm{~mL} / \mathrm{g})$, and homogenized on ice (Asaro et al., 2011). Both hepatopancreas homogenate and hemolymph were centrifuged at $1 \times 10^{4} \mathrm{rpm}$ at $4{ }^{\circ} \mathrm{C}$, for $15 \mathrm{~min}$. After centrifugation, the supernatant was collected, stored at $-20{ }^{\circ} \mathrm{C}$ then lyophilized.

\section{Protein estimation}

After lyophilization, crude extracts were weighed and dissolved in phosphate buffer saline (PBS). The total protein concentration of both extracts was determined using the method of Lowry et al. (1951). Bovine serum albumin (BSA) was used as a standard. The extracts were used in experiments based on their protein concentrations.

\section{Cells and cell cultures}

Human cervical carcinoma (HeLa), human hepatocellular carcinoma (HepG2), human breast cancer cell lines (MCF-7 and MDA-MB-231) and normal human lung cells (WI-38) were obtained from the Holding company for biological products and vaccines (VACSERA), Giza, Egypt. Cells were propagated in RPMI-1640 medium supplemented with $10 \%$ heat-inactivated fetal bovine serum (FBS) and $1 \%$ antibiotic (penicillin), then incubated in $5 \% \mathrm{CO}_{2}$ at $37^{\circ} \mathrm{C}$ for growth. After that, the cells were seeded on 96 well plates at a concentration of $1 \times 10^{4}$ cells/well $(100 \mu \mathrm{l} / \mathrm{well})$ for $24 \mathrm{~h}$. After seeding, cells were treated with serial concentrations of hepatopancreas and hemolymph extracts (from 0.125 to $8 \mathrm{mg} / \mathrm{ml}$ ) and incubated at $37^{\circ} \mathrm{C}$ and $5 \% \mathrm{CO}_{2}$ for $48 \mathrm{~h}$.

\section{Cell proliferation by MTT assay}

The antiproliferative effects of hepatopancreas and hemolymph were evaluated using the 3-[4,5-methylthiazol-2-yl]-2,5-diphenyl-tetrazolium bromide (MTT) assay (Mosmann, 1983). Briefly, after treatment with both extracts for $48 \mathrm{~h}$, fresh medium containing MTT dye was added to cells $(10 \mu \mathrm{l} / \mathrm{well})$ and incubated at $37^{\circ} \mathrm{C}$ for $4 \mathrm{~h}$ to allow the formation of formazan crystals in viable cells only. In order to solubilize these crystals, $100 \mu \mathrm{l}$ of Dimethyl sulfoxide (DMSO) was added to each well, then the plates were centrifuged for 5 minutes at $4000 \mathrm{rpm}$. The absorbance was measured at $560 \mathrm{~nm}$ using a Bio-Tek microplate reader ELISA. The experiment was performed in triplicates. The percentage of cell viability was calculated according to the following formula:

Cell viability $(\%)=\left(\mathrm{A}_{\mathrm{T}} / \mathrm{A}_{\mathrm{C}}\right) \times 100$.

Where $A_{T}$ denotes the absorbance of treated cells and $A_{C}$ denotes the absorbance of the control (untreated cells).

The $\mathrm{IC}_{\mathbf{5 0}}$ (the concentration that inhibits the growth of $50 \%$ of cells) values of each sample were determined from a plot of dose-response curve between dose concentration on $\mathrm{X}$-axis and cell inhibition percentage on the $\mathrm{Y}$-axis. 


\section{Analysis of Cellular DNA Content Using Propidium Iodide}

Flow cytometry is used to analyze cell cycle progression by measuring the percentage of cellular DNA content (Pozarowski and Darzynkiewicz, 2004). HeLa cells were seeded at a density of $1 \times 10^{4}$ into a 6-well plate and incubated with $\mathrm{IC}_{\mathbf{5 0}}$ concentrations of each extract at $37{ }^{\circ} \mathrm{C}$ in $5 \% \mathrm{CO}_{2}$ atmosphere for $48 \mathrm{~h}$. Cells without any treatment were used as a control. Then, cells were resuspended in PBS (500 $\mu \mathrm{l})$ prior to being fixed at $70 \%$ cold ethanol for at least $2 \mathrm{~h}$ at $-20^{\circ} \mathrm{C}$. The fixed cells were washed twice with PBS, then treated with $500 \mu \mathrm{l}$ PI/RNase (4:1 propidium iodide/Ribonuclease A) and incubated for $30 \mathrm{~min}$ in the dark at room temperature. The cellular DNA content was measured using a flow cytometer (FACSCalibur, Becton Dickinson, USA).

\section{Annexin V/PI double staining assay}

$1 \times 10^{4} \mathrm{HeLa}$ cells were seeded into a 6-well plate and treated with an $\mathrm{IC}_{\mathbf{5 0}}$ concentration of hepatopancreas and hemolymph extracts. After $48 \mathrm{~h}$ of incubation, the cells were centrifuged (1000 rpm for $5 \mathrm{~min}$ ), resuspended in $500 \mathrm{ml} 1 \mathrm{X}$ binding buffer and stained with $5 \mu \mathrm{l}$ of PI and $5 \mu \mathrm{l}$ of Annexin-V-FITC (Annexin V-FITC Apoptosis Detection Kit). Finally, the cells were incubated in the dark for $5 \mathrm{~min}$ at room temperature. The cells were analyzed and the percentage of total apoptotic and necrotic cells was calculated using a BD FACSCalibur flow cytometer.

\section{DPPH radical scavenging assay}

Free radical scavenging activities of both extracts were determined by the 1, 1diphenyl-2-picrylhydrazyl (DPPH) assay as described by Brand-Williams et al. (1995). In brief, $1 \mathrm{ml}$ of DPPH methanolic solution $(0.1 \mathrm{mM}$, in $95 \%$ methanol $)$ was mixed with $3 \mathrm{ml}$ of varying concentrations of each extracts or standard $(3.9-1000 \mu \mathrm{g} / \mathrm{ml})$ and incubated for $30 \mathrm{~min}$ at room temperature. Ascorbic acid (Vitamin C) was used as a standard (positive control), and absorbance at $517 \mathrm{~nm}$ was measured with a spectrophotometer (UV-VIS Milton Roy). The DPPH scavenging effect (\%) was calculated according to the following formula:

DPPH scavenging effect $(\%)=\left[\left(\mathrm{A}_{\mathrm{B}}-\mathrm{A}_{\mathrm{S}}\right) / \mathrm{A}_{\mathrm{B}}\right] \times 100$.

Where $A_{B}$ was the Absorbance of blank and $A_{S}$ was the Absorbance in presence of samples or standard.

The $\mathrm{IC}_{50}$ values (the concentration of extracts with the ability to decrease $50 \%$ of the initial DPPH concentration) were determined using the Log dose inhibition curve.

\section{Effect of hepatopancreas and hemolymph extracts on $\mathrm{H}_{2} \mathrm{O}_{2}$-induced oxidative stress in WI-38 cells}

Normal human lung WI-38 cells were seeded in culture plates at a density of $1 \times 10^{6}$ cells $/ \mathrm{ml}$. After $24 \mathrm{~h}$, the cells were washed twice and divided into 6 groups. The control group was represented by cells without any treatment. Hepatopancreas and hemolymph extracts $\left(2 \mathrm{mg} / \mathrm{ml}\right.$ in PBS) were added to some cells $\left(2^{\text {nd }}\right.$ and $3^{\text {rd }}$ groups). 
Oxidative stress was induced by treating the cells with freshly prepared hydrogen peroxide $\left(\mathrm{H}_{2} \mathrm{O}_{2}\right)$ with a final concentration of $500 \mu \mathrm{M}$ in a FBS-free DMEM medium $\left(4^{\text {th }}\right.$ group). The other cells were subjected to equal volumes of each extracts and $\mathrm{H}_{2} \mathrm{O}_{2}\left(5^{\text {th }}\right.$ and $6^{\text {th }}$ groups). All cells were incubated for $24 \mathrm{~h}$ at $37^{\circ} \mathrm{C}$ in a $5 \% \mathrm{CO}_{2}$ atmosphere. After incubation, the activities of superoxide dismutase (SOD), catalase (CAT), the content of reduced glutathione (GSH) and malondialdehyde (MDA) were measured by commercial colorimetric assay kits obtained from Bio-diagnostic Co., Giza, Egypt.

\section{Hemolytic activity assay}

Hemolytic activities of both extracts were assayed on human erythrocytes as described by Malagoli (2007). Fresh blood samples collected in tubes containing anticoagulant as EDTA $(3: 1 \mathrm{v} / \mathrm{v})$ were centrifuged at $2000 \mathrm{rpm}$ for $5 \mathrm{~min}$. Briefly, a suspension of red blood cells in sterile PBS was incubated with various serial concentrations of each extract $(0.25-8 \mathrm{mg} / \mathrm{ml})$ for $1 \mathrm{~h}$ at room temperature. After incubation, the cells were centrifuged at $1 \times 10^{4} \mathrm{rpm}$ for $5 \mathrm{~min}$ and the supernatant was used to measure the absorbance of the liberated hemoglobin at $570 \mathrm{~nm}$. Sterile phosphate buffer saline and $10 \%$ Triton X-100 were used as a negative control ( $0 \%$ hemolysis) and positive control (100\% hemolysis), respectively. The experiment was conducted in triplicate. The hemolysis percentage for each sample was calculated by the following equation:

$$
\text { Hemolysis }(\%)=100 \times\left[\left(\mathrm{A}_{S}-\mathrm{A}_{\mathrm{N} . \mathrm{C}}\right) /\left(\mathrm{A}_{\mathrm{P} . \mathrm{C}}-\mathrm{A}_{\mathrm{N} . \mathrm{C}}\right] .\right.
$$

Where $A_{S}$ is the sample absorbance, $A_{N . C}$ is the negative control absorbance, and $A_{P . C}$ is the positive control absorbance.

\section{SDS-polyacrylamide gel electrophoresis}

Sodium dodecyl sulfate polyacrylamide gel electrophoresis (SDS-PAGE) is used to separate proteins of both samples according to their molecular weights. According to Laemmli (1970), SDS-PAGE was performed at a total acrylamide concentration of $12 \%$. In the presence of the sample buffer $(70 \mathrm{mM}$ Tris- $\mathrm{HCl}, \mathrm{pH} 6.8,11.4 \%$ glycerol, $3 \%$ SDS, $0.01 \%$ bromophenol blue, and $5 \% \mathrm{~b}$-mercaptoethanol), the samples were boiled at $95^{\circ}$ for $5 \mathrm{~min}$. Protein samples were immediately loaded into wells, and electrophoresis was carried out at $200 \mathrm{~V}$ for $35-40 \mathrm{~min}$. After separation, the gel was stained by Coomassie Brilliant Blue (CBB G-250) in order to visualize protein bands.

\section{Statistical analysis}

Statistical analysis was carried out using SPSS 22.0. The data was expressed as a mean value \pm SE and data was analyzed using a Student's t-test and a One-way ANOVA followed by the Tukey's test. When the p-value was 0.05 , a statistically significant difference in meaning was reported. 


\section{RESULTS}

\section{Cell proliferation by MTT assay}

The viability of four human cancer cell lines (HeLa, MCF-7, MDA-MB-231 and HepG2) was inhibited in a dose-dependent manner after being treated with hepatopancreas and hemolymph extracts of the blue crab C. sapidus for $48 \mathrm{~h}$ (Figure 1). Hepatopancreas possessed more cytotoxic activity than hemolymph against all tested cancer cells. Growth of more than $90 \%$ of HeLa, MCF-7 and HepG2 cells were inhibited after being treated with hepatopancreas at $8 \mathrm{mg} / \mathrm{ml}$ while hemolymph inhibited only about $75 \%$ of the growth of the same cells at the same concentration. Low or no cytotoxicity was detected on normal lung cells (WI-38) after treatment with both extracts. It is clear that HeLa cells were the most susceptible cancer cell line to both extracts. Therefore, cell cycle arrest and apoptotic analysis were carried out on these cells only.

$\mathbf{A}$

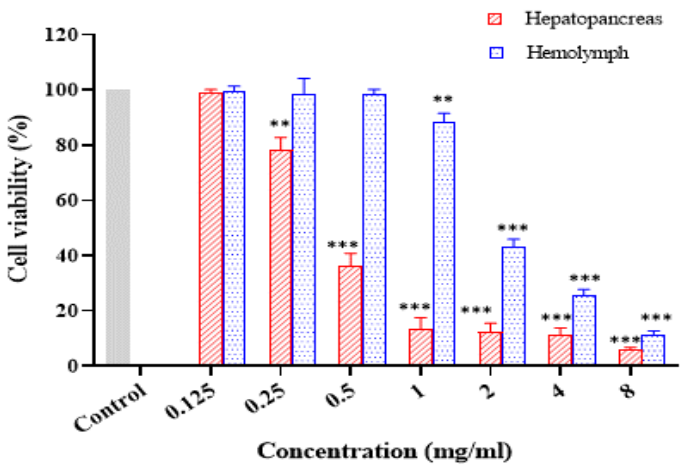

C

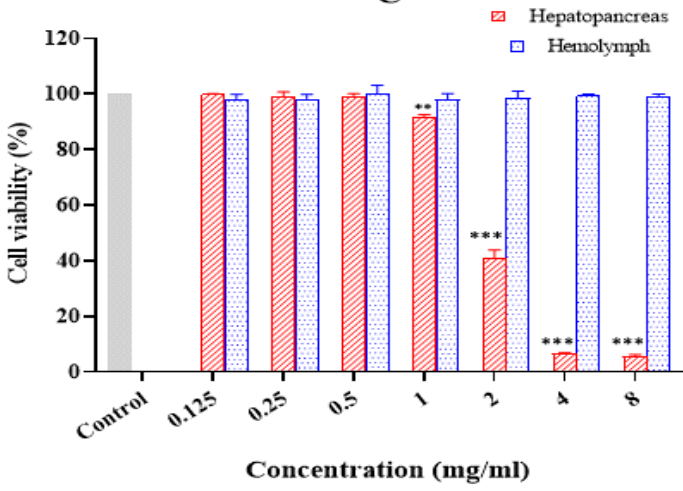

B

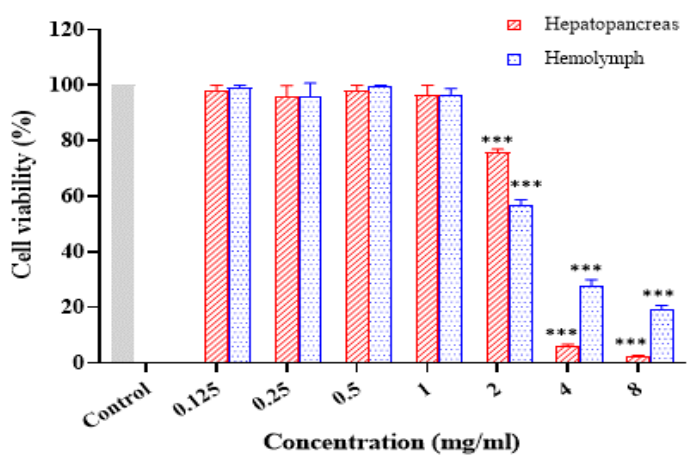

D

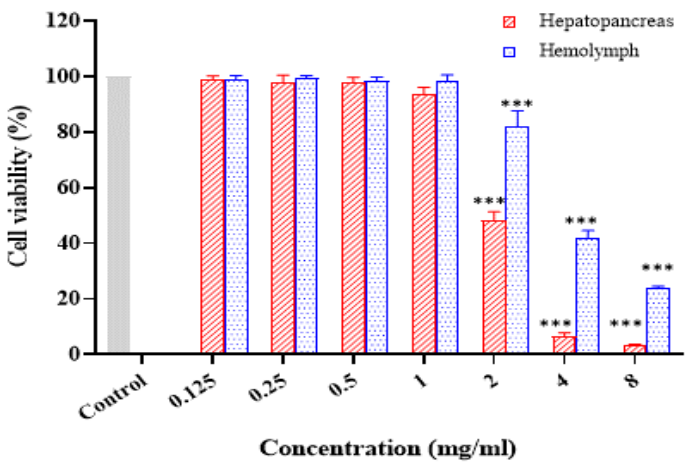

Figure 1. Effects of hepatopancreas and hemolymph extracts of $C$. sapidus on cell proliferation of different human cell lines at different concentrations. A: Cervical (HeLa), B: breast (MCF-7), C: breast (MDA-MB-231) and D: liver (HepG2) cell lines. Non-treated cells are used as a control. Bars sharing superscript of stars $(*)$ differ significantly as compared against control $(* * P<0.01$, *** $P<0.001)$ using a One-way ANOVA followed by the Tukey's test. 


\section{Analysis of Cellular DNA Content Using Propidium Iodide}

Hepatopancreas and hemolymph extracts induce cell cycle arrest at the G2/M phase after $48 \mathrm{~h}$ treatment of HeLa cells (Figure 2). Both extracts induced a statistically significant increase in the percentage of the cells at the G2/M phase from $8.25 \%$ in untreated cells to $31.02 \%$ and $28.66 \%$ in the treated cells with hepatopancreas and hemolymph, respectively $(P<0.001)$. Also, both extracts significantly increase the preG1 population of cells treated with hepatopancreas $(18.21 \%)$ and hemolymph $(12.37 \%)$ $(P<0.001)$. While the population of cells at G0-G1 and S phases significantly declined after being treated with both extracts $(P<0.05)$. 

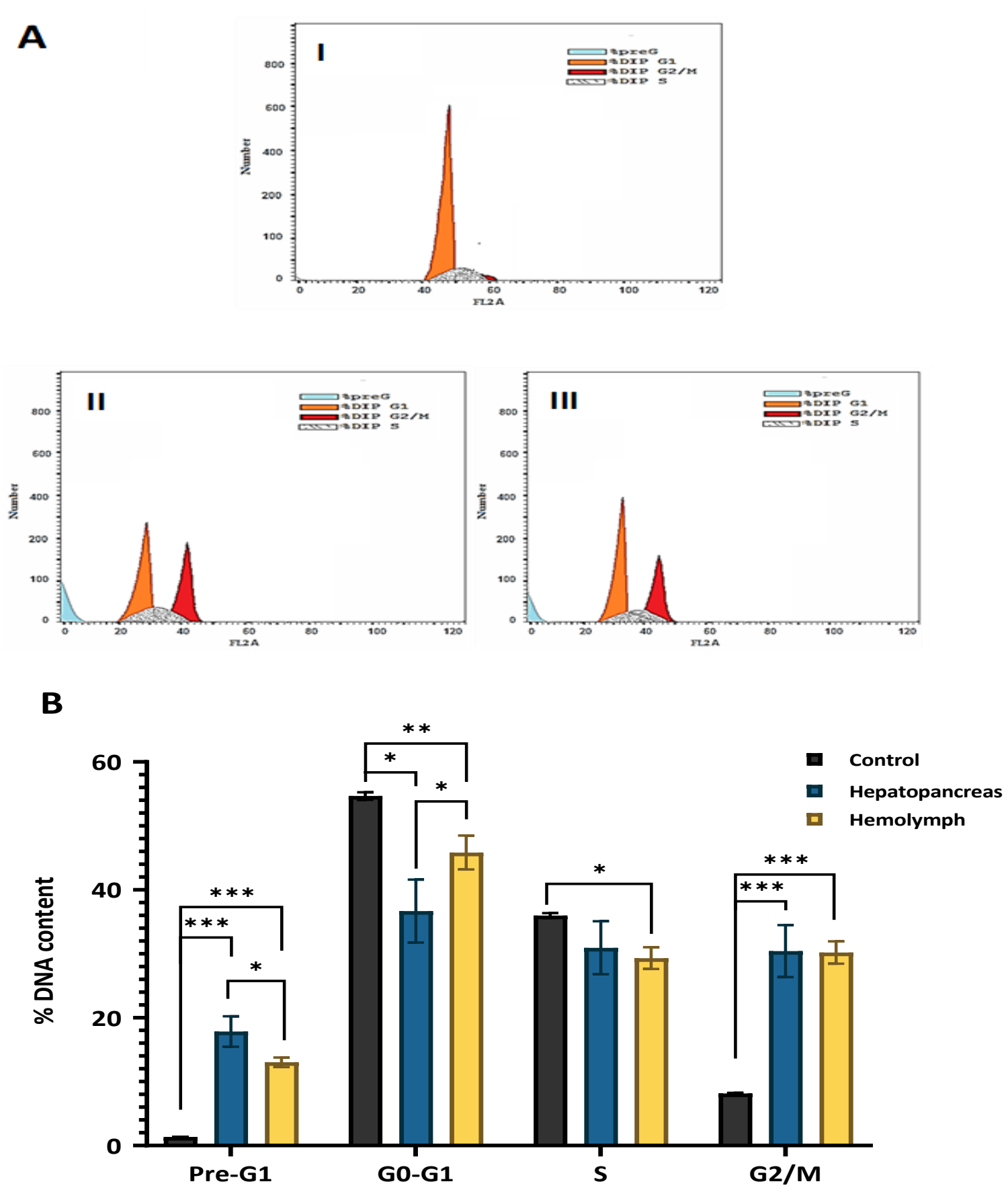

Figure 2. Cell cycle distributions of HeLa cells treated with $\mathrm{IC}_{50}$ values of hepatopancreas and hemolymph extracts for $48 \mathrm{~h}$. (A) Representative profiles of cell cycle distribution in HeLa cells before and after treatments: I) Untreated HeLa cells, II) HeLa cells treated with hepatopancreas extract and III) HeLa cells treated with hemolymph extract. (B) The percentages of cell populations in pre-G1, G0-G1, S and G2/M phases. Bars sharing superscript of stars $(*)$ differ significantly $(* P<0.05, * * P<0.01, * * * P<0.001)$ using a One-way ANOVA followed by the Tukey's test. 


\section{Annexin V/PI double staining assay}

Hepatopancreas and hemolymph extracts induced apoptotic cell death in HeLa cells (Figure 3 ). After $48 \mathrm{~h}$ treatment with $\mathrm{IC}_{50}$ of both extracts, a significant increase in early and late apoptotic cells population was observed as compared to control cells $(P<$ $0.001)$. The percentage of total apoptotic cell was significantly increased from $0.75 \%$ in non-treated cells to $16.02 \%$ and $10.66 \%$ in treated cells with hepatopancreas and hemolymph extracts respectively $(P<0.001)$.
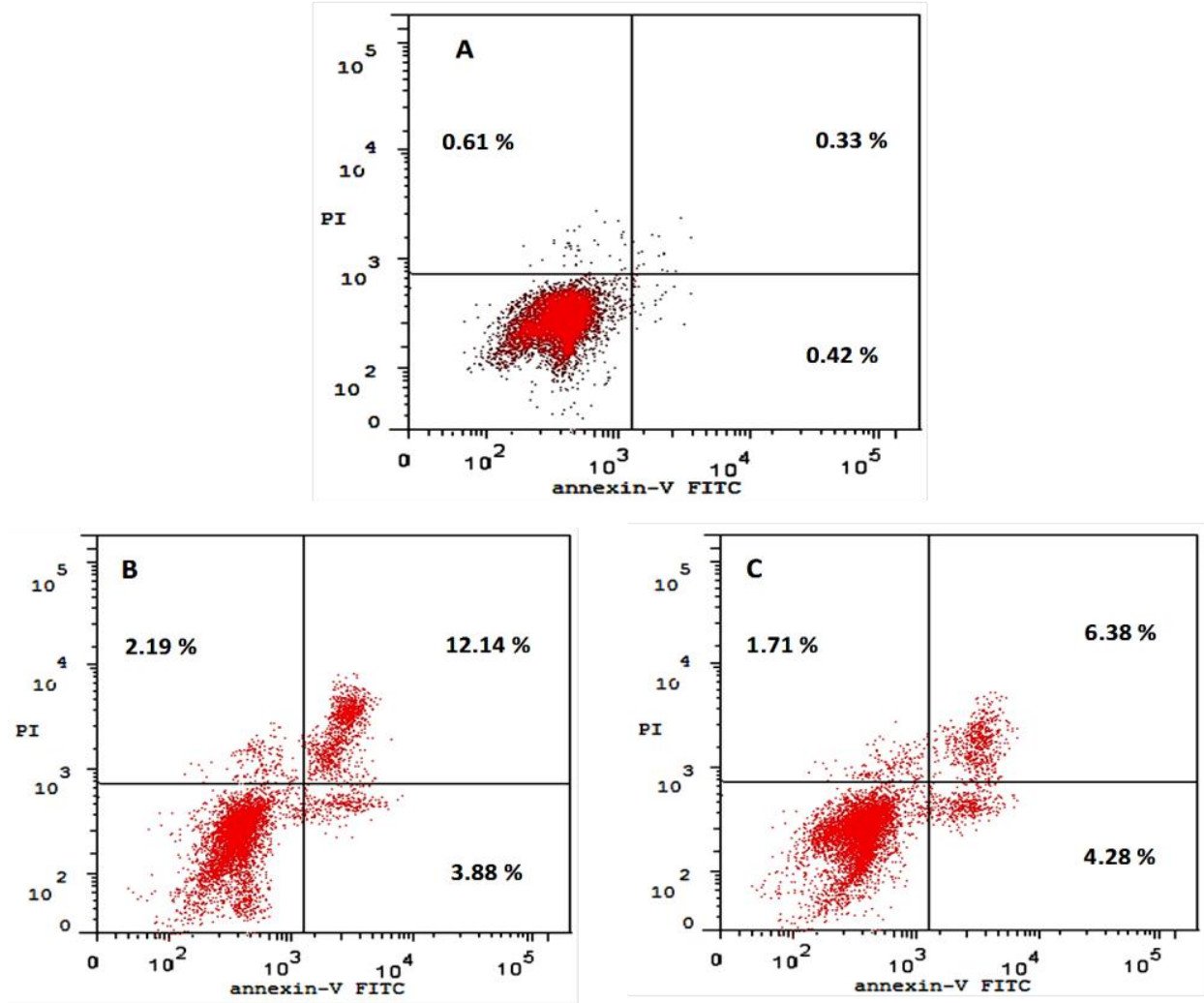

Figure 3. The contour diagram of Annexin V/PI Flow Cytometry shows the apoptotic potential effects of the hepatopancreas and hemolymph of the blue crab, C. sapidus. A) Untreated HeLa cells, B) HeLa cells after $48 \mathrm{~h}$ treatment with $\mathrm{IC}_{50}$ of hepatopancreas extract and C) $\mathrm{HeLa}$ cells after $48 \mathrm{~h}$ treatment with $\mathrm{IC}_{50}$ of hemolymph extract. Lower left quadrants show viable cells (An -, PI -), whereas the lower right quadrants represent early apoptotic cells (An +, PI -). Necrotic cells (An -, PI +) are found in the upper left quadrants, while late apoptotic cells $(\mathrm{An}+, \mathrm{PI}+)$ are found in the upper right quadrants.

\section{DPPH radical scavenging assay}

Hepatopancreas and hemolymph extracts of $C$. sapidus showed a potent radical scavenging activity in a dose-dependent manner (Figure 4). Overall, hepatopancreas extracts displayed higher antioxidant properties with a significantly lower $\mathrm{IC}_{50}$ value of $38.99 \mu \mathrm{g} / \mathrm{ml}$ than that of hemolymph $\left(\mathrm{IC}_{50}\right.$ value $\left.=464 \mu \mathrm{g} / \mathrm{ml} ; P<0.001\right)$. Hepatopancreas extract exhibited similar radical-scavenging activities as those of ascorbic acid, particularly at higher concentrations. 


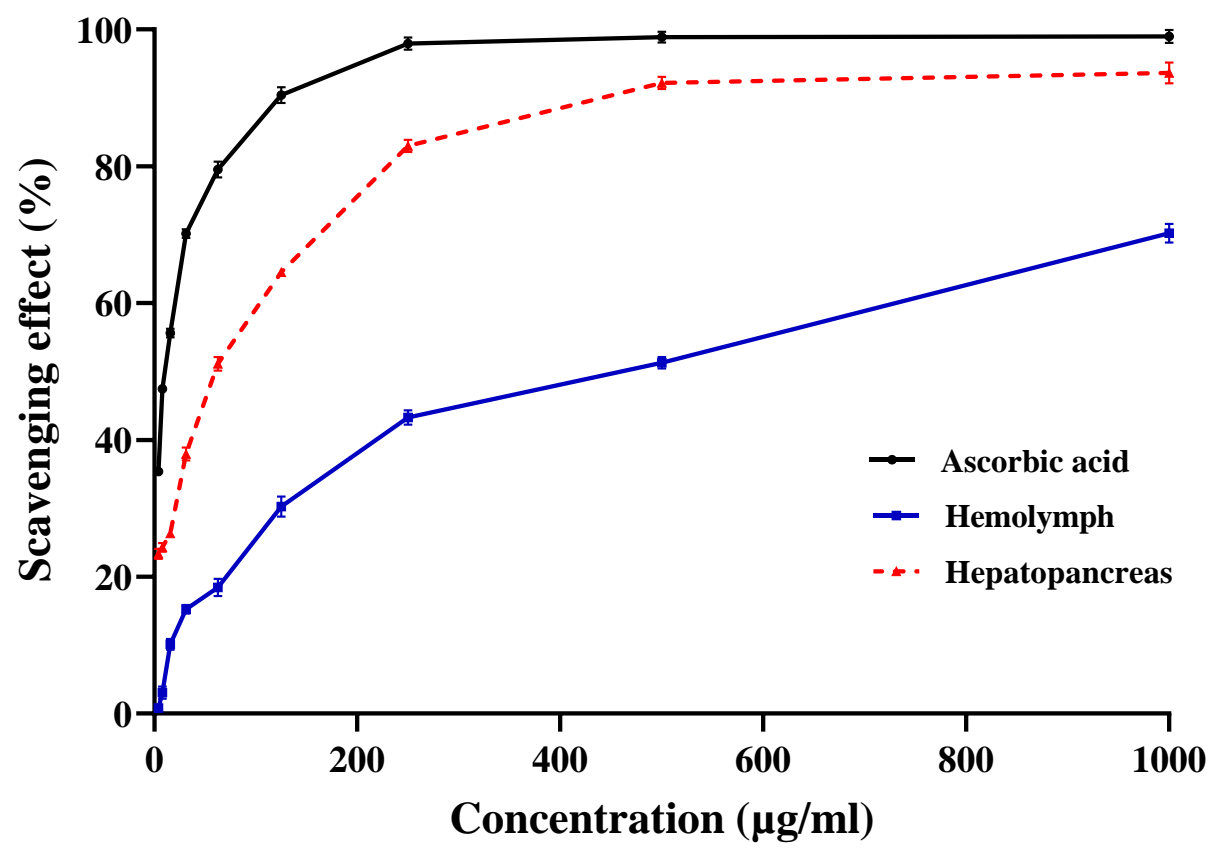

Figure 4. DPPH radical-scavenging activity of the hepatopancreas and hemolymph extracts comparing with the standard (Ascorbic acid).

\section{Antioxidative effect of hepatopancreas and hemolymph extracts on $\mathrm{H}_{2} \mathrm{O}_{2}$-induced oxidative stress in WI-38 cells}

The activities of antioxidant enzymes (SOD and CAT) in $\mathrm{H}_{2} \mathrm{O}_{2}$-treated cells were significantly depleted as compared to control cells $(4.38 \pm 0.01$ to $2.33 \pm 0.25$ units of $\mathrm{SOD} / \mathrm{mg}$ protein and $2.31 \pm 0.09$ to $0.58 \pm 0.1$ units of CAT/mg protein, $P<0.001)$. Hepatopancreas and hemolymph extracts restored and induced SOD (4.05 \pm 0.06 and $3.89 \pm 0.23 \mathrm{U} / \mathrm{mg}$ protein $)$ and CAT $(1.69 \pm 0.14$ and $1.68 \pm 0.15 \mathrm{U} / \mathrm{mg}$ protein $)$ activities (Figure 5A and $\mathrm{B}$ ). Figure (5C) shows that both extracts significantly increased levels of GSH in cells from $0.13 \pm 0.006$ in cells exposed to $\mathrm{H}_{2} \mathrm{O}_{2}$ to $0.25 \pm 0.03 \mathrm{nmol} / \mathrm{ml}$ and 0.23 $\pm 0.02 \mathrm{nmol} / \mathrm{ml}$ for hepatopancreas and hemolymph, respectively $(P<0.05)$. A remarkably depletions in oxidative stress biomarker, MDA levels, from $30.43 \pm 1.02$ in $\mathrm{H}_{2} \mathrm{O}_{2}$-treated cells to $16.38 \pm 0.98$ and $18.03 \pm 1.08 \mathrm{nmol} / \mathrm{ml}$ were observed in cells treated with hepatopancreas and hemolymph extracts, respectively (Figure 5D). 
$\mathbf{A}$

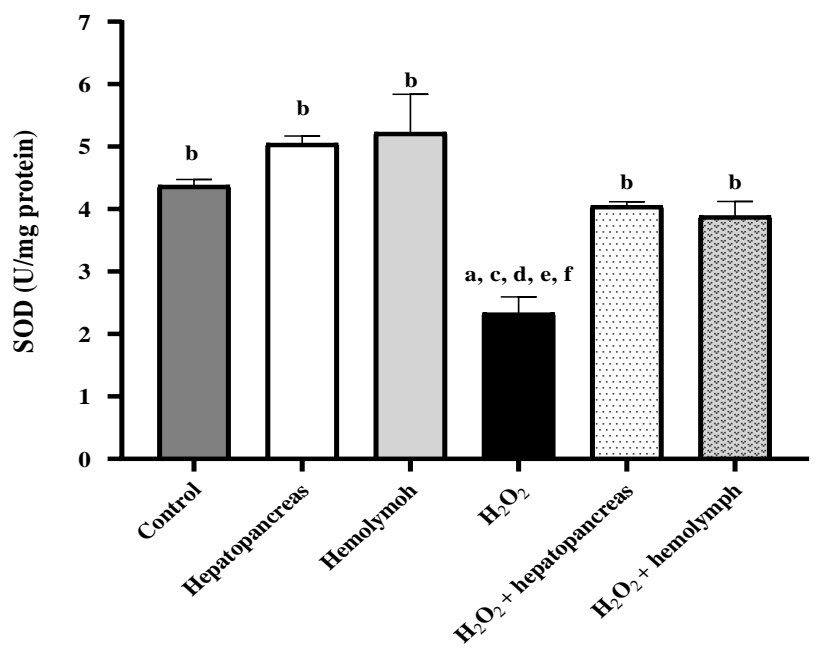

$\mathbf{C}$

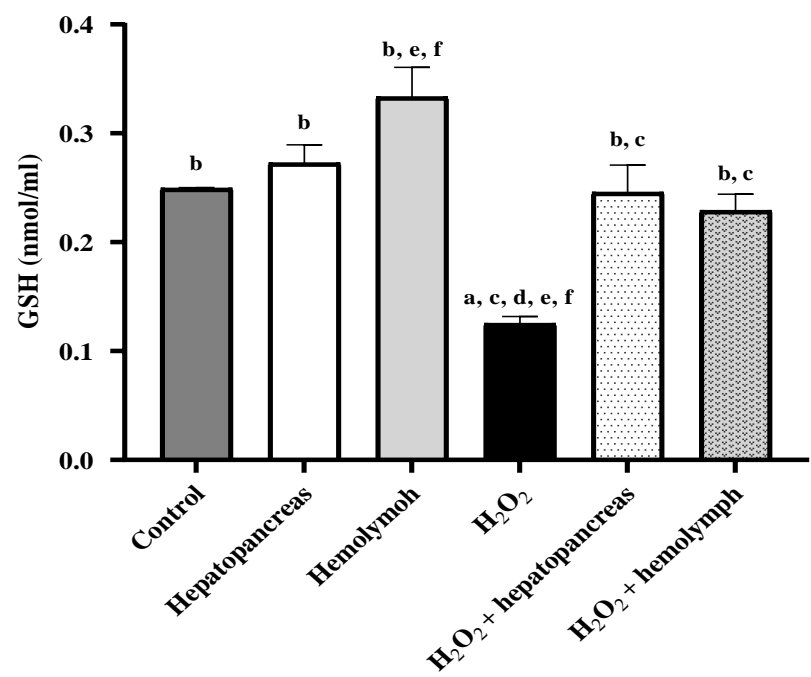

B

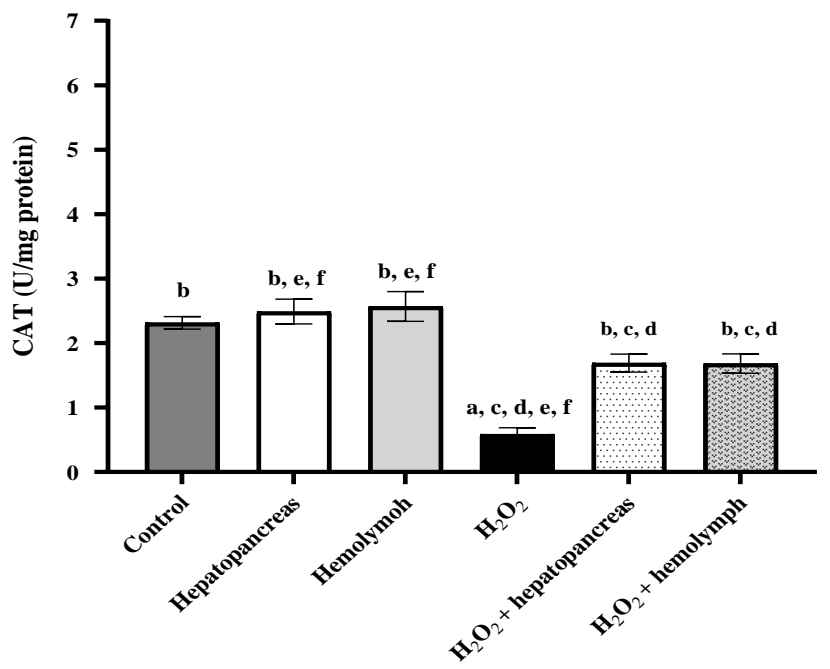

$\mathbf{D}$

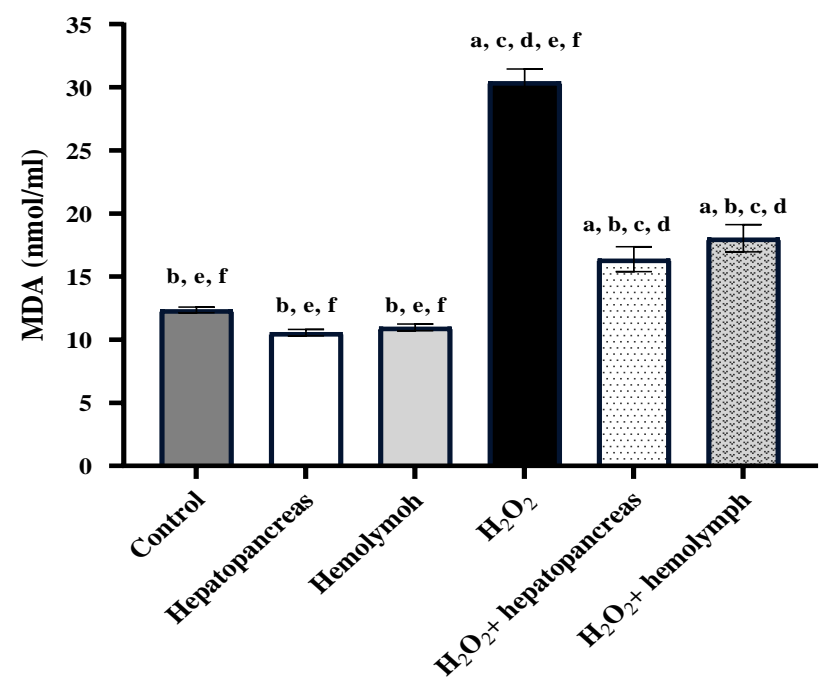

Figure 5. Antioxidant effect of hepatopancreas and hemolymph extracts from C. sapidus on normal lung cells (WI-38). Activities of SOD (A), CAT (B) and levels of GSH (C) and MDA (D) were assayed in all cell groups. Bars with different letters (a-f) differ significantly by a $P<0.05$ (a versus control, b versus $\mathrm{H}_{2} \mathrm{O}_{2}$, c versus hepatopancreas, $d$ versus hemolymph, e versus $\mathrm{H}_{2} \mathrm{O}_{2}+$ hepatopancreas and $\mathrm{f}$ versus $\mathrm{H}_{2} \mathrm{O}_{2}+$ hemolymph) using a One-way ANOVA followed by the Tukey's test. 


\section{Hemolytic activity assay}

Hemolytic activities of hepatopancreas and hemolymph were evaluated on erythrocytes. Both extracts displayed low or no hemolytic activity on erythrocytes (Figure 6), as compared to negative and positive controls.

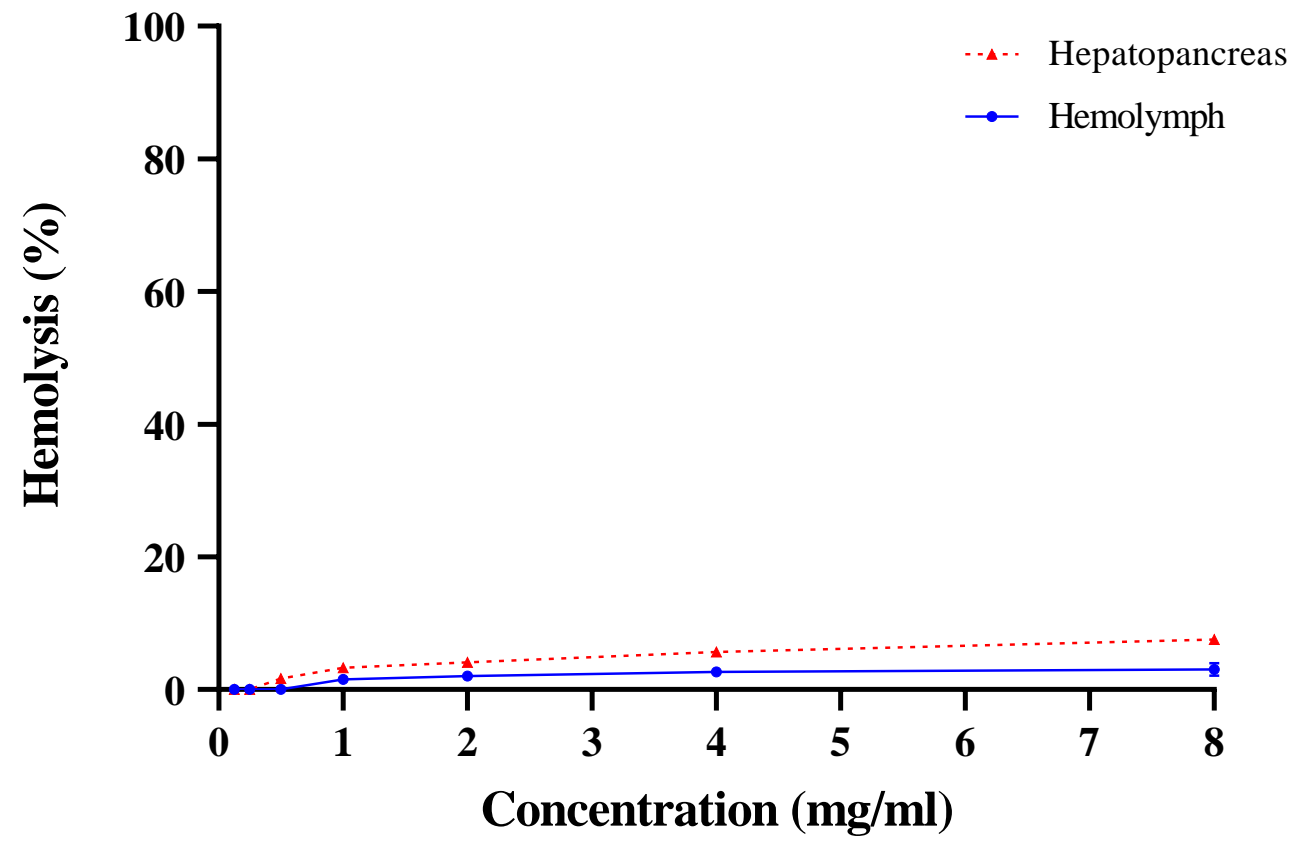

Figure 6. The hemolytic activities of hepatopancreas and hemolymph extracts on erythrocytes.

\section{SDS-polyacrylamide gel electrophoresis}

Quantitative analysis of proteins from the hepatopancreas and hemolymph of the blue crab $C$. sapidus was performed using SDS-PAGE (Figure 7). The SDS profile represented protein bands found in both extracts. Hemolymph showed an increased number of bands than hepatopancreas. In hemolymph, the results revealed the presence of proteins in the range of between 10 and $\sim 130 \mathrm{kDa}$ (lane 2). Meanwhile, about eight protein bands with molecular masses of 10, 17, 20, 25, 34, 50, 66 and $\sim 90 \mathrm{kDa}$ were detected in the hepatopancreas (lane3). Several bands with molecular weights of 10 , 17, 35, 50, 70 and 95 KDa were observed commonly in both samples. 


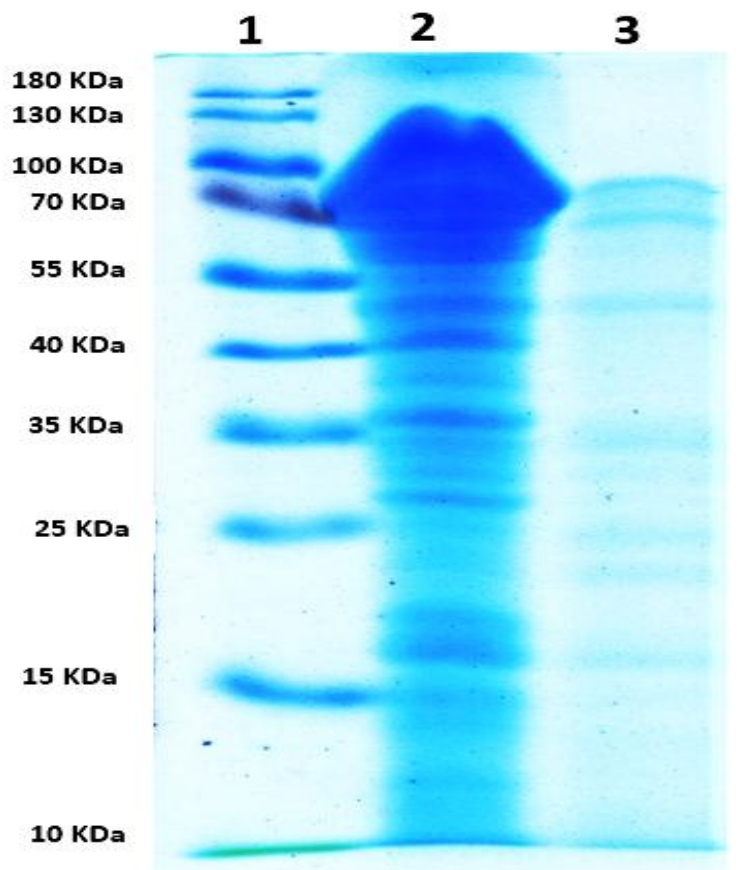

Figure 7. The SDS-PAGE gel shows the protein profile in the hemolymph and hepatopancreas extracts of C. sapidus. Lane 1: marker, Lane 2: protein extracts from the hemolymph and Lane 3: protein extracts from the hepatopancreas.

\section{DISCUSSION}

Edible crabs are one of the most valuable sources of human nutrition. Among the benefits of these creatures, they possess structurally diverse bioactive components including some anticancer and antioxidant agents (Jiang $\boldsymbol{e t}$ al., 2017; Mohamed $\boldsymbol{e t}$ al., 2017; Katran et al., 2019). Accordingly, they used as a natural source in pharmaceutical applications.

In the present study, both hepatopancreas and hemolymph extracts of $C$. sapidus showed a relative degree of cytotoxicity against all tested cancer cell lines in a dosedependent manner with some significant preference for hepatopancreas. This variation in the cytotoxicity between two extracts on the same tested cancer cell lines can be attributed to the significant difference in their antioxidant properties and protein profiles. In most invertebrates, several immune proteins are often synthesized in hepatopancreas then released to the hemolymph upon immune-stimulation (Röszer, 2014). However, limited studies have examined the cytotoxic properties of hepatopancreas extracted from crabs against cancer cell lines. Kuznetsov et al. (2012) found that a protease inhibitor (66 KDa) from Paralithodes camtschatica slowed down cell spreading and suppressed the growth of HeLa cells. SDS-PAGE gel analysis in the present study revealed the presence of a protein band with a similar molecular weight of PC inhibitor that may interpret the antiproliferative activity of the hepatopancreas extract against HeLa cells. 
The anticancer activities of protease inhibitors are related to their ability to inhibit the function of proteases that play an important role in cancer development, progression and metastasis (Castro Guillén et al., 2010).

Similar previous studies have reported the antitumor effects of hemolymph in other crabs like Atergatis roseus \& Eriphia verrucosa (Salama and Mona, 2018), Scylla serrata (Pramanik et al., 2010) and Dromia dehaani (Priya and Ravichandr, 2015a; RethnaPriya et al., 2019). These antiproliferative activities of hemolymph were attributed to glycoproteins such as lectins and hemocyanin with molecular weights of $\sim 75$ KDa. Remarkably, a protein band with an apparent molecular weight similar to that of the above glycoproteins was found in the hemolymph extract of $C$. sapidus. Hemocyanin and lectins possess a wide spectrum of biological effects such as antiviral, antiparasitic and antitumor activities (Zhang et al., 2004; Rizvi et al., 2007; Guo et al., 2011; Cheung et al., 2015). Marine lectins can recognize and bind to specific carbohydrate structures or motifs on the cell membranes of cancer cells that lead to growth inhibition and induction of the apoptotic pathway in these cells (Cheung et al., 2015).

The present study showed that both extracts exhibited selective antiproliferative activities against cancer cells only, with no cytotoxicity against erythrocytes and normal lung cells. The selectivity of these molecules may be attributed to the fundamental differences in membrane lipid asymmetry between normal and cancerous cells (Hoskin and Ramamoorthy, 2008). Neutrally charged phospholipids such as phosphatidylcholines and sphingomyelins are located in the outer leaflet of normal cell membranes. While the outer leaflet of cancer cell membranes is characterized by the presence of negative phospholipids such as phosphatidylserines and those facilitate specific recognition of tumor cells by cationic peptides (Zalba and Ten Hagen, 2017; Bernardes and Fialho, 2018; Wang et al., 2017). The hemolymph of crabs is rich in naturally occurring cationic peptides such as callinectin which was previously isolated from the same blue crab Callinectes sapidus (Noga et al., 2011). Such peptides exhibit a broad spectrum of cytotoxicity against bacterial and cancer cells with no or limited activity against normal healthy cells (Fredrick and Ravichandran, 2012; Bernardes and Fialho, 2018; Lei et al., 2019). The electrostatic attraction between callinectin and negatively charged phospholipids of cancer cells may participate in the selective antiproliferative activities of both extracts. The selectivity of these molecules may provide useful leads to overcome the cancer cell resistance to chemotherapy and may help to reduce toxicity and risk factors associated with the use of traditional anticancer drugs due to a lack of specificity for cancer cells (Alfarouk et al., 2015; Oun et al., 2018).

Cervical cancer is one of the leading causes of death in women worldwide, with the African continent having the highest incidence and mortality (Khazaei et al., 2019). Based on the findings of flow cytometry analysis, the $\mathrm{IC}_{50}$ of both extracts caused $\mathrm{G} 2 / \mathrm{M}$ 
cell cycle arrest of HeLa cells by significantly increasing the accumulation of cell populations in this phase with a pronounced increase in the pre-G1 populations (dead cells). After $48 \mathrm{~h}$ of treatment, Annexin V and PI double staining demonstrated that both extracts induced apoptosis of HeLa cells. Interestingly, the protein electrophoretic profiles of both extracts showed a protein band with a $17 \mathrm{KDa}$ molecular size, similar to the small classes of lectins isolated from marine invertebrates. The antiproliferative activities of these lectins may be related to the loss of membrane integrity and late-stage apoptosis in cancer cells (Fujii et al., 2012).

In the current study, hepatopancreas extract was found to possess higher antioxidant activity than hemolymph. This indicated the ability of both extracts to decrease oxidative stress by scavenging ROS. DPPH is a stable free radical at room temperature that can be used to assess in vitro antioxidant properties of any compound (Kedare and Singh, 2011). The ability of the extract to scavenge DPPH radical was determined by the decline in the absorbance as a result of a conversion of DPPH solution (diphenylpicrylhydrazyl) to the reduced form (Diphenylpicrylhydrazine) after receiving a hydrogen atom from extract (Molyneux, 2003). The antioxidant properties of both extracts on DPPH radical scavenging is thought to be due to their hydrogen donating ability. These results of the present study are consistent with previous studies wherein the hemolymph of Ocypoda macrocera (Sivaperumal et al., 2013), Liagore rubromaculata (Priya et al., 2014) and Scylla serrate (Sujeetha et al., 2015) have been reported to possess radical scavenging activities.

Oxidative stress is caused in cells and tissues as a result of the imbalance between the accumulation of reactive oxygen species (ROS) and the production of antioxidants that detoxify these reactive products (Pizzino et al., 2017). The increased production of ROS and cellular oxidative stress in cells has long been associated with an elevated metabolic rate and gene mutations (Liou and Storz, 2010; Bhardwaj and He, 2020). $\mathrm{H}_{2} \mathrm{O}_{2}$ is one of the major ROS that induces oxidative stress in cells that leads to DNA damage (Coyle and Kader, 2007). In the current study, $\mathrm{H}_{2} \mathrm{O}_{2}$ induced lipid peroxidation in WI-38 cells, leading to increase the accumulation of the oxidative stress biomarker (MDA). It also decreased GSH levels and the activities of SOD and CAT in cells. The present results show that hepatopancreas and hemolymph extracts alone or as cotreatment with $\mathrm{H}_{2} \mathrm{O}_{2}$ significantly enhanced intracellular antioxidant parameters (CAT, SOD and GSH) and reduced lipid peroxidation (MDA content) in normal human lung cells. This study agreed with previous studies that proved the ability of compounds isolated from marine invertebrates to exert cytoprotective activities on cells by inducing activities of SOD, CAT and increasing GSH levels (Roel $\boldsymbol{e t}$ al., 2015). These antioxidants may be the cause of the antiproliferative activities of both extracts. Potent antioxidants may decelerate the growth of cancer cells, decrease persistent oxidative stress, or inhibit cancer progression (Ilghami et al., 2019). 


\section{CONCLUSION}

The present study revealed for the first time the cytoprotective and inhibitory properties of the hepatopancreas and hemolymph of the edible blue crab Callinectes sapidus. Both extracts could be effectively used as potential sources for anticancer drugs discovery because of their selective antiproliferative effects. The results indicated that both extracts inhibit growth and proliferation of HeLa cells through induction of apoptosis and cell cycle arrest at G2/M phase. This study showed that the hepatopancreas extract exhibited more antioxidant, antiproliferative activities and apoptosis induction than hemolymph.

\section{REFERENCES}

Abou El-Ezz, R.A.; Ibrahim, A.; Habib, E.; Wahba, A.; Kamel, H.; Afifi, M.; Hassanean, H. and Ahmed, S. (2017). Review of natural products from marine organisms in the Red Sea. Int. J. Pharm. Sci. Res., 8: 940.

Alfarouk, K.O.; Stock, C. M.; Taylor, S.; Walsh, M.; Muddathir, A.K.; Verduzco, D.; Bashir, A.H.H.; Mohammed, O.Y.; Elhassan, G.O.; Harguindey, S.; Reshkin, S.J.; Ibrahim, M.E. and Rauch, C. (2015). Resistance to cancer chemotherapy: failure in drug response from ADME to P-gp. Cancer Cell Int., 15: 1-13. https://doi.org/10.1186/s12935-015-0221-1

Asaro, A.; Del Valle, C. and Mañanes, A. (2011). Amylase, maltase and sucrase activities in hepatopancreas of the euryhaline crab Neohelice granulata (Decapoda: Brachyura: Varunidae): Partial characterization and response to low environmental salinity. Sci. Mar., 75: 517-524. https://doi.org/10.3989/scimar.2011.75n3517

Bernardes, N. and Fialho, A.M. (2018). Perturbing the dynamics and organization of cell membrane components: a new paradigm for cancer-targeted therapies. Int. J. Mol. Sci., 19: 3871. https://doi.org/10.3390/ijms19123871

Bhardwaj, V. and He, J. (2020). Reactive oxygen species, metabolic plasticity, and drug resistance in cancer. Int. J. Mol. Sci., 21: 3412. https://doi.org/10.3390/ijms21103412

Blunt, J.W.; Carroll, A.R.; Copp, B.R.; Davis, R.A.; Keyzers, R.A. and Prinsep, M.R. (2018). Marine natural products. Nat. Prod. Rep., 35: 8-53. https://doi.org/10.1039/C8NP00092A

Brand-Williams, W.; Cuvelier, M.E. and Berset, C. (1995). Use of a free radical method to evaluate antioxidant activity. LWT - Food Sci. Technol., 28: 25-30. https://doi.org/10.1016/S0023-6438(95)80008-5

Castro-Guillén, J.L.; García-Gasca, T. and Blanco-Labra, A. (2010). Protease inhibitors as anticancer agents. New Approaches Treat. Cancer., 91-124.

Chen, J. (2016). The Cell-Cycle Arrest and Apoptotic Functions of p53 in Tumor Initiation and Progression. Cold Spring Harb. Perspect. Med., 6: a026104. https://doi.org/10.1101/cshperspect.a026104 
Cheung, R.C.F.; Wong, J.H.; Pan, W.; Chan, Y.S.; Yin, C.; Dan, X. and Ng, T.B. (2015). Marine lectins and their medicinal applications. Appl. Microbiol. Biotechnol., 99: 3755-3773. https://doi.org/10.1007/s00253-015-6518-0

Coyle, C.H. and Kader, K.N. (2007). Mechanisms of $\mathrm{H}_{2} \mathrm{O}_{2}$-induced oxidative stress in endothelial cells exposed to physiologic shear stress. ASAIO J., 53: 17-22. https://doi.org/10.1097/01.mat.0000247157.84350.e8

Datta, D.; Talapatra, S.N. and Swarnakar, S. (2016). An overview of lectins from freshwater and marine macroinvertebrates. World Scientific News, 77-87.

Fredrick, W.S. and Ravichandran, S. (2012). Hemolymph proteins in marine crustaceans. Asian Pac. J. Trop. Biomed., 2: 496-502. https://doi.org/10.1016/S22211691(12)60084-7

Fujii, Y.; Dohmae, N.; Takio, K.; Kawsar, S.M.A.; Matsumoto, R.; Hasan, I.; Koide, Y.; Kanaly, R.A.; Yasumitsu, H.; Ogawa, Y.; Sugawara, S.; Hosono, M.; Nitta, K.; Hamako, J.; Matsui, T. and Ozeki, Y. (2012). A lectin from the mussel Mytilus galloprovincialis has a highly novel primary structure and induces glycan-mediated cytotoxicity of globotriaosylceramide-expressing lymphoma cells. J. Biol. Chem., 287: 44772-44783. https://doi.org/10.1074/jbc.M112.418012

Guo, D.; Wang, H.; Zeng, D.; Li, X.; Fan, X. and Li, Y. (2011). Vaccine potential of hemocyanin from Oncomelania hupensis against Schistosoma Japonicum. Parasitol. Int., 60: 242-246. https://doi.org/10.1016/j.parint.2011.03.005

Hoskin, D.W. and Ramamoorthy, A. (2008). Studies on anticancer activities of antimicrobial peptides. Biochim. Biophys. Acta BBA-Biomembr., 1778: 357-375. https://doi.org/10.1016/j.bbamem.2007.11.008

Huang, Z.; Aweya, J.J.; Zhu, C.; Tran, N.T.; Hong, Y.; Li, S.; Yao, D. and Zhang, Y. (2020). Modulation of crustacean innate immune response by amino acids and their metabolites: inferences from other species. Front. Immunol., 11: 2812. https://doi.org/10.3389/fimmu.2020.574721

Ilghami, R.; Barzegari, A.; Mashayekhi, M.R.; Letourneur, D.; Crepin, M. and Pavon-Djavid, G. (2019). The conundrum of dietary antioxidants in cancer chemotherapy. Nutr. Rev., 78: 65-76. https://doi.org/10.1093/nutrit/nuz027

Jiang, W.; Hu, S.; Li, S. and Liu, Y. (2017). Biochemical and antioxidant properties of peptidic fraction generated from crab (Portunus trituberculatus) shells by enzymatic hydrolysis. Int. J. Food Sci. Technol., 52: 2479-2488. https://doi.org/10.1111/ijfs.13533

Katran, H.; Brestovac, B. and Dye, D. (2019). Crab ash extract has anti-proliferative effects on SK-MEL-28 melanoma cells and induces a cellular stress response and metabolic changes. Trop. J. Nat. Prod. Res., 3: 113-123. https://doi.org/ 10.26538/tjnpr/v3i4.3

Kedare, S.B. and Singh, R.P. (2011). Genesis and development of DPPH method of antioxidant assay. J. Food Sci. Technol., 48: 412-422. https://doi.org/10.1007/s13197011-0251-1 
Khazaei, Z.; Sohrabivafa, M.; Mansori, K.; Naemi, H. and Goodarzi, E. (2019). Incidence and mortality of cervix cancer and their relationship with the human development index in 185 countries in the world: An ecology study in 2018. Adv. Hum. Biol., 9: 222. https://doi.org/10.4103/AIHB.AIHB_15_19

Küçükgülmez, A.; Çelik, M.; Yanar, Y.; Ersoy, B. and Çikrikçi, M. (2006). Proximate composition and mineral contents of the blue crab (Callinectes sapidus) breast meat, claw meat and hepatopancreas. Int. J. Food Sci. Technol., 41: 1023-1026. https://doi.org/10.1111/j.1365-2621.2006.01159.x

Kuznetsov, S.A.; Golyshev, S.A.; Rudenskaya, Y.A.; Isaev, V.A.; Kuranova, I.P. and Rudenskaya, G.N. (2012). A novel endogenous inhibitor from the hepatopancreas of the Kamchatka crab Paralithodes camtschaticus. Russ. J. Bioorganic Chem., 38: 290-297. https://doi.org/10.1134/S1068162012020069

Laemmli, U.K. (1970). Cleavage of structural proteins during the assembly of the head of bacteriophage T4. Nature, 227: 680-685. https://doi.org/10.1038/227680a0

Lei, J.; Sun, L.; Huang, S.; Zhu, C.; Li, P.; He, J.; Mackey, V.; Coy, D.H. and He, Q. (2019). The antimicrobial peptides and their potential clinical applications. Am. J. Transl. Res., 11: 3919.

Li, X.; Cui, Z.; Liu, Y.; Song, C. and Shi, G. (2013). Transcriptome analysis and discovery of genes involved in immune pathways from hepatopancreas of microbial challenged mitten crab Eriocheir sinensis. PloS One, 8: e68233. https://doi.org/10.1371/journal.pone.0068233

Liou, G.Y. and Storz, P. (2010). Reactive oxygen species in cancer. Free Radic. Res., 44: 479-496. https://doi.org/10.3109/10715761003667554

Lowry, O.H.; Rosebrough, N.J.; Farr, A.L. and Randall, R.J. (1951). Protein measurement with the Folin phenol reagent. J. Biol. Chem., 193: 265-275.

Malagoli, D. (2007). A full-length protocol to test hemolytic activity of palytoxin on human erythrocytes. Invertebr. Surviv. J., 4: 92-94.

Mohamed, M.; Sani, N.I.M.; Ismail, A. and Mokhtar, N.F. (2017). Cytotoxicity and anti-cancer effect of mangrove crab (Scylla serrata) soup on human leukemic Jurkat cells. Eur. J. Pharm. Med. Res., 2: 192-195.

Molyneux, P. (2003). The use of the stable radical Diphenylpicrylhydrazyl (DPPH) for estimating antioxidant activity. 26.

Mosmann, T. (1983). Rapid colorimetric assay for cellular growth and survival: application to proliferation and cytotoxicity assays. J. Immunol. Methods, 65: 55-63. https://doi.org/10.1016/0022-1759(83)90303-4

Noga, E.J.; Stone, K.L.; Wood, A.; Gordon, W.L. and Robinette, D. (2011). Primary structure and cellular localization of callinectin, an antimicrobial peptide from the blue crab. Dev. Comp. Immunol., 35: 409-415. https://doi.org/10.1016/j.dci.2010.11.015 
Ortega, P.; e Sá, M.G.; Custódio, M.R. and Zanotto, F.P. (2011). Separation and viability of gill and hepatopancreatic cells of a mangrove crab Ucides cordatus. Vitro Cell. Dev. Biol. Anim., 47: 346-349. https://doi.org/10.1007/s11626-011-9402-y

Oun, R.; Moussa, Y.E. and Wheate, N.J. (2018). The side effects of platinum-based chemotherapy drugs: a review for chemists. Dalton Trans., 47: 6645-6653. https://doi.org/10.1039/C8DT00838H

Parrinello, D.; Sanfratello, M.A.; Celi, M. and Vazzana, M. (2015). Hemocyte types and some plasmatic properties of two edible crabs Cancer borealis and Cancer pagurus. Invertebr. Surviv. J., 12: 195-202.

Pizzino, G.; Irrera, N.; Cucinotta, M.; Pallio, G.; Mannino, F.; Arcoraci, V.; Squadrito, F.; Altavilla, D. and Bitto, A. (2017). Oxidative stress: harms and benefits for human health. Oxid. Med. Cell. Longev., 2017. https://doi.org/10.1155/2017/8416763 Pozarowski, P. and Darzynkiewicz, Z. (2004). Analysis of cell cycle by flow cytometry. In: Checkpoint controls and cancer. Humana Press, 281: 301-312. https://doi.org/10.1385/1-59259-811-0:301

Pramanik, J.; Chatterjee, U.; Mondal, G.; Campana, P.T. and Chatterjee, B.P. (2010). Tn/T specific agglutinin from estuarine crab Scylla serrata with potent mitogenic activity on mouse splenocytes and antiproliferative effect on hepatocellular carcinoma (HepG2) cell. Glycobiol. Insights, 2. https://doi.org/10.4137/GBI.S4214

Priya, E.R. and Ravichandr, S. (2015a). Anti-cancer activity of brachyuran crab Dromia dehaani (Rathbun, 1923). Asian J. Biotechnol., 7: 119-128. https://doi.org/10.3923/ajbkr.2015.119.128

Priya, E.R. and Ravichandr, S. (2015b). Anticancer compounds of Calappa calappa L. (1758). Int. J. Zool. Res., 11: 107. https://doi.org/10.3923/ijzr.2015.107.111

Priya, E.R.; Ravichandran, S. and Jawaharlal, P. (2014). Antimicrobial and antioxidant proteins from the crab Liagore rubromaculata (De Haan, 1835). World J. Pharm. Pharm. Sci., 3: 9.

RethnaPriya, E.; Ravichandran, S.; Gobinath, T.; Tilvi, S. and Devi, S.P. (2019). Functional characterization of anti-cancer sphingolipids from the marine crab Dromia dehanni. Chem. Phys. Lipids, 221: 73-82. https://doi.org/10.1016/j. chemphyslip. 2019.03.010

Rizvi, I.; Riggs, D.R.; Jackson, B.J. and McFadden, D.W. (2007). Keyhole limpet hemocyanin: an effective adjunct against melanoma in vivo. Am. J. Surg., 194: 628-632. https://doi.org/10.1016/j.amjsurg.2007.08.005

Roel, M.; Rubiolo, J.A.; Ternon, E.; Thomas, O.P.; Vieytes, M.R. and Botana, L.M. (2015). Crambescin C1 exerts a cytoprotective effect on HepG2 cells through metallothionein induction. Mar. Drugs, 13: 4633-4653. https://doi.org/10.3390 /md13084633 
Rőszer, T. (2014). The invertebrate midintestinal gland ("hepatopancreas") is an evolutionary forerunner in the integration of immunity and metabolism. Cell Tissue Res., 358: 685-695. https://doi.org/10.1007/s00441-014-1985-7

Salama, W.M. and Mona, M.M. (2018). In vitro anti-tumor effects of hemocyanin isolated from Atergatis roseus and Eriphia verrucosa crabs. J. Cancer Biomed. Res., 2: 10-19. https://doi.org/10.21608/jcbr.2019.34742

Sánchez-Salgado, J.L.; Pereyra, M.; Agundis, C.; Vivanco-Rojas, O.; SierraCastillo, C.; Alpuche-Osorno, J. and Zenteno, E. (2017). Participation of lectins in crustacean immune system. Aquac. Res., 48: 4001-4011. https://doi.org/ 10.1111 /are. 13394

Shi, X.Z.; Li, X.C.; Wang, S.; Zhao, X.F. and Wang, J.X. (2010). Transcriptome analysis of hemocytes and hepatopancreas in red swamp crayfish, Procambarus clarkii, challenged with white spot syndrome virus. Invertebr. Surviv. J., 7: 119-131.

Sivaperumal, P.; Kamala, K.; Natarajan, E. and Dilipan, E. (2013). Antimicrobial peptide from crab haemolypmh of Ocypoda macrocera (Milne Edwards 1852) with reference to antioxidant: a case study. International Journal of Pharmacy and Pharmaceutical Sciences, 5: 672-680.

Sujeetha, M.; Sharmila, S.; Jayanthi, J. and Ragunathan, M. (2015). Antioxidant property of some extracts derived from the mud crab, genus Scylla serrata. Int. J. Phytopharm., 6: 111-113.

Wang, L.; Dong, C.; Li, X.; Han, W. and Su, X. (2017). Anticancer potential of bioactive peptides from animal sources. Oncol. Rep., 38: 637-651. https://doi.org/10.3892/or.2017.5778

Wei, Y.; Lin, D.; Xu, Z.; Gao, X.; Zeng, C. and Ye, H. (2020). A possible role of crustacean cardioactive peptide in regulating immune response in hepatopancreas of mud crab. Front. Immunol., 11: 711. https://doi.org/10.3389/fimmu.2020.00711

Wu, F.; Xie, Z.; Yan, M.; Li, Q.; Song, J.; Hu, M. and Wang, Y. (2019). Classification and characterization of hemocytes from two Asian horseshoe crab species Tachypleus tridentatus and Carcinoscorpius rotundicauda. Sci. Rep., 9: 1-10. https://doi.org/10.1038/s41598-019-43630-8

Zalba, S. and Ten Hagen, T.L.M. (2017). Cell membrane modulation as adjuvant in cancer therapy. Cancer Treat. Rev., 52: 48-57. https://doi.org/10.1016/j.ctrv.2016.10.008 Zhang, X.; Huang, C. and Qin, Q. (2004). Antiviral properties of hemocyanin isolated from shrimp Penaeus monodon. Antiviral Res., 61: 93-99. https://doi.org/10.1016/j.antiviral.2003.08.019 